\title{
Vibrio alginolyticus infection in the white shrimp Litopenaeus vannamei confirmed by polymerase chain reaction and $16 \mathrm{~S}$ rDNA sequencing
}

\author{
Chun-Hung Liu ${ }^{1}$, Winton Cheng ${ }^{2}$, Jung-Ping Hsu ${ }^{3}$, Jiann-Chu Chen ${ }^{1, *}$ \\ ${ }^{1}$ Department of Aquaculture, National Taiwan Ocean University, Keelung, Taiwan 202, ROC \\ ${ }^{2}$ Department of Aquaculture, National Pingtung University of Science and Technology, Pingtung, Taiwan 912, ROC \\ ${ }^{3}$ Pingtung Hsien Livestock Disease Control Center, Pingtung, Taiwan 900, ROC
}

\begin{abstract}
A Gram-negative, rod-shaped bacterium identified as Vibrio alginolyticus was isolated from diseased Litopenaeus vannamei (also called Penaeus vannamei) in Taiwanese culture ponds. The diseased shrimp displayed poor growth, anorexia, inactivity, reddish pleural borders of antennae, uropods and telson, opaque and whitish musculature, and mortality. In histological preparations, melanized hemocytic granulomas were observed in the connective tissue around hemal sinuses together with hemocytic aggregation in necrotic musculature. Six isolates of Vibrio were collected from diseased shrimp at 3 farms, and these were evaluated for characteristics including morphology, physiology, biochemistry and sensitivity to antibiotics. The results indicated that the isolates belonged to a single species that grew in 1 to $8 \% \mathrm{NaCl}_{\text {, at }} 10$ to $40^{\circ} \mathrm{C}$ and on TCBS (thiosulfatecitrate-bile sucrose) agar, and that gave positive catalase, O/F (Oxidation/Fermentation), lysine decarboxylase, gelatinase and cytochrome-oxidase tests. Identification of CH003 (1 of 6 isolates) was confirmed by PCR assay for $V$. alginolyticus (expected amplicon $1486 \mathrm{bp}$ ). The 16S rDNA sequence (GenBank accession number AY373027) gave 99.9\% sequence identity to $V$. alginolyticus (GenBank accession number X74690). The calculated $96 \mathrm{~h} \mathrm{LD}_{50}$ dose of the isolated strain was $3.0 \times 10^{5}$ colony forming units (CFU) shrimp ${ }^{-1}\left(6.6 \times 10^{4} \mathrm{CFU} \mathrm{g}^{-1}\right)$.
\end{abstract}

KEY WORDS: Litopenaeus vannamei $\cdot$ Bacterial disease · Vibrio alginolyticus $\cdot$ PCR $\cdot$ 16S rDNA sequencing

Resale or republication not permitted without written consent of the publisher

\section{INTRODUCTION}

Over the past $15 \mathrm{yr}$, shrimp culture in Taiwan has been mainly based on indigenous species such as black tiger shrimp Penaeus monodon, kuruma shrimp Maruspenaeus japonicus (also called Penaeus japonicus) and red-tail shrimp Fenneropenaeus penicillatus (also called Penaeus penicillatus). The industry has suffered serious economic losses due to infectious diseases due to bacteria such as Vibrio harveyi (Liu et al. 1996a,b), Photobacterium damsela (Song et al. 1993) and Vibrio alginolyticus (Lee et al. 1996a,b), and viruses such as monodon baculovirus (MBV) (Lightner et al. 1987, Chen et al. 1989), white spot syndrome virus (WSSV) (Lo \& Kou 1998) and yellow head virus (YHV) (Wang \& Chang 2000). Disease outbreaks are associated with increases in the proportion of potentially pathogenic species in the Vibrio population of culture pond water (Lavilla-Pitogo et al. 1998, Sung et al. 2001). As a result, exotic white shrimp Litopenaeus vannamei (also called Penaeus vannamei) were introduced in 1985 (Lin et al. 1990) and have been widely cultivated since. Production reached $11012 \mathrm{t}$ in 2003 or about 5 times the combined production from indige- 
nous penaeid shrimp (2205 t). It was also higher than the production of farmed freshwater prawns Macrobarchium rosenbergii (10045 t).

Traditionally, identification of a bacterial pathogen is dependent on its growth on selective media and characterization by morphological and biochemical tests (Baumann \& Schubert 1984, Diggles et al. 2000). Recently, taxonomic studies have been developed based on 16S rRNA targeted polymerase chain reactions (PCR) (Kim \& Jeong 2001), 16S rDNA genotyping using polymerase chain reaction/restriction fragment length polymorphisms (PCR/RFLP) (Urakawa et al. 1997), analysis of 16S-23S rDNA intergenic spacers (Kong et al. 1999), random amplified polymorphic (RAPD) DNAPCR analysis (Aznar et al. 1993, Sudheesh et al. 2002) and DNA-DNA hybridization assays (Costa et al. 1998).

Since 2001, Taiwanese shrimp farmers have experienced disease problems linked to production declines in farmed Litopenaeus vannamei and associated with signs of disease different to those of Taura syndrome virus (TSV) (Yu \& Song 2000). The disease signs include poor growth, anorexia, inactivity, whitish musculature and death. This paper reports on the isolation and characterization of Vibrio alginolyticus from the muscle of such diseased shrimp and its comparison to the reference strain $V$. alginolyticus ATCC17749. Experimental infections were also carried out with 1 isolate $(\mathrm{CH} 003)$ to test pathogenicity.

\section{MATERIALS AND METHODS}

Isolation of bacteria. Six diseased shrimp showing whitish musculature and inactivity were collected from each of 5 farms in Pingtung, Taiwan, from May to September 2002. Bacteria were isolated from the muscle on tryptic soy agar (TSA supplemented with $2.5 \%$ $\mathrm{NaCl}$, Difco) (TNA) plates incubated at $28^{\circ} \mathrm{C}$ for $18 \mathrm{~h}$. For subsequent tests, they were incubated on either TNA or thiosulfate-citrate-bile sucrose (TCBS, Difco) supplemented with $2.5 \% \mathrm{NaCl}$.

To isolate bacteria, the shrimp cuticle was surface sterilized using $70 \%(\mathrm{v} / \mathrm{v})$ alcohol and then cut with a sterile scalpel to expose the underlying discolored musculature. A sterile loop was touched to the discolored tissue and then streaked onto TNA, that was then incubated at $28^{\circ} \mathrm{C}$ for $24 \mathrm{~h}$ until visible bacterial colonies developed. One of the dominant colonies was then selected and re-streaked onto TNA to obtain pure cultures for identification tests.

Bacterial morphology and growth. Gram-stained smears from pure cultures of bacterial isolates were examined by light microscopy to determine cell size and morphology. After passage of test strains in tryptic soy broth (TSB, Difco) supplemented with $2.5 \% \mathrm{NaCl}$
(TNB) and selection on TCBS agar supplemented with $2.5 \% \mathrm{NaCl}$ for $24 \mathrm{~h}$ at $28^{\circ} \mathrm{C}$, motility was tested by the hanging-drop method. Both colony color and growth in TCBS agar were recorded. The ability of the strains to grow in TNA at different temperatures was tested over a period of $7 \mathrm{~d}$. Tolerance to $\mathrm{NaCl}$ was determined by the addition of different concentrations of $\mathrm{NaCl}$ (1 to $12 \%)$ to TNA cultures and examination for growth after 1 wk (Cheng \& Chen 1998).

Biochemical characteristics. Test cultures were grown on TNA for $24 \mathrm{~h}$ at $28^{\circ} \mathrm{C}$ and then inoculated into test media for biochemical tests (Facklam \& Carey 1985). Parallel tests were carried out with commercial API 20E Kits (ATB System, bioMerieux) for bacteriological identification. The reactions were compared with the reference strain Vibrio alginolyticus ATCC (American Type Culture Collection) 17749 (Sakazaki 1968).

For antibiotic sensitivity tests, isolates were spread on TNA plates and exposed to antibiotic discs containing 2,4-diamino-6,7-diisopropyl pteridine phosphate $(\mathrm{O} / 129,150 \mu \mathrm{g}$, Creative Microbiologicals), novobiocin (30 $\mu \mathrm{g}, \mathrm{BBL})$, neomycin $(30 \mu \mathrm{g}, \mathrm{BBL})$, nitrofurantoin (300 $\mu \mathrm{g}, \mathrm{BBL})$, sulfisoxazole $(250 \mu \mathrm{g}, \mathrm{BBL})$, chloramphenicol $(30 \mu \mathrm{g}, \mathrm{BBL})$, tetracycline $(30 \mu \mathrm{g}, \mathrm{BBL})$ and kanamycin $(30 \mu \mathrm{g}, \mathrm{BBL})$, respectively.

DNA isolation. Bacteria were grown at $28^{\circ} \mathrm{C}$ in TNB broth for $24 \mathrm{~h}$ and harvested by centrifugation at 7000 $\times g$ for $20 \mathrm{~min}$ at $4^{\circ} \mathrm{C}$. The nucleic acid of pelleted bacteria was extracted using a Genomic DNA purification Kit (No. A1120, Promega) and stored at $-20^{\circ} \mathrm{C}$, until used for polymerase chain reaction (PCR) tests.

Polymerase chain reaction. The specific PCR primers for identification of Vibrio alginolyticus 16S rDNA were designed based on the method described by Ruimy et al. (1994) in the GenBank database (Benson et al. 1994) using the CLUSTAL program (Higgins \& Sharp 1988). They were VA16F1 (5'-ATT GAA GAG TTT GAT CAT GGC TCA GA-3') and VA16R1 (5'CAG CTA TTA ACT ACA CTA-3'), and VA16F2 (5'CCT TCG GGT TGT AAA GCA CT-3') and VA16R2 (5'-TCC TCC CGT AGT TGA AAC TAC CTA CT-3'), respectively. The PCR reaction buffer contained $50 \mathrm{mM}$ Tris-HCl buffer ( $\mathrm{pH}$ 9), containing $50 \mathrm{mM} \mathrm{KCl}$, $1 \%$ Triton X-100 (Boehringer Mannheim), $2.5 \mathrm{mM}$ $\mathrm{MgCl}_{2}, 5 \mathrm{U}$ Taq polymerase, $0.25 \mathrm{mM}$ dNTPs, and $1 \mu \mathrm{M}$ of each primer. PCR reactions were performed as follows: 30 cycles of denaturation at $94^{\circ} \mathrm{C}$ for $1 \mathrm{~min}$, annealing at $50^{\circ} \mathrm{C}$ for $1 \mathrm{~min}$ and elongation at $72^{\circ} \mathrm{C}$ for $2 \mathrm{~min}$, followed by a $10 \mathrm{~min}$ extension at $72^{\circ} \mathrm{C}$ and cooling to $4^{\circ} \mathrm{C}$. The PCR fragments were subjected to electrophoresis on a $1.5 \%$ agarose gel for length differences, and amplified DNA fragments were cloned into the pGEM-T Easy vector following the instructions provided (Promega). Recombinant bacteria were iden- 
tified by blue/white screening and confirmed by PCR. Plasmids containing the insert were purified (Promega minipreps) and used as a template for DNA sequencing.

Sequencing of $16 \mathrm{~S}$ rDNA. Nucleotide sequence analysis was performed using the dideoxynucleotide chain termination method (Sanger et al. 1977) on a DNA sequencer (Model 373A, Applied Biosystems). Plasmid DNA at $1 \mu \mathrm{g}$ was used for sequencing with a Dye Terminator Cycle Sequencing Kit (Applied Biosystems) and subjected to electrophoresis on a $6 \%$ denaturing gel. Clones were sequenced with the M13 forward and reverse primers.

Infectivity trials. Strain $\mathrm{CH} 003$ was grown on TNA for $24 \mathrm{~h}$ at $28^{\circ} \mathrm{C}$. Colonies were scraped off the plates and suspended in $0.85 \% \mathrm{NaCl}$, at a concentration of $2 \times$ $10^{8} \mathrm{CFU}$ (colony-forming units) $\mathrm{ml}^{-1}$. Bacterial concentration was calculated based on a standard curve created from a series of known concentrations of bacterial solution and absorbance. A series of 10-fold dilutions of this bacterial suspension was made with $0.85 \% \mathrm{NaCl}$ solution, and $20 \mu$ l of each dilution was injected into the ventral sinus of the cephalothorax. Shrimp (4 to $5 \mathrm{~g}$ in the intermolt stage) were obtained from a commercial farm and acclimated in the laboratory for $1 \mathrm{wk}$ prior to experimentation. The dose of bacteria per shrimp ranged from $4 \times 10^{4}$ to $4 \times 10^{6} \mathrm{CFU}$ (see Table 3 ). A challenge test was conducted in triplicate with test and control groups comprising 10 shrimp for each replicate. Shrimp injected with equal volumes of sterile saline solution served as the control group. After injection, each group was held in a separate 601 glass aquarium (10

Table 1. Morphological and physiological characteristics of the isolated strains $(\mathrm{n}=6)$ from diseased Litopenaeus vannamei in comparison to the reference strain Vibrio alginolyticus. ATCC17749. +: positive; -: negative; TSA: tryptic soy agar; TCBS: thiosulfate-citrate-bile sucrose agar; Y: yellow colonies

\begin{tabular}{|c|c|c|}
\hline Character & Isolated strain & ATCC17749 \\
\hline Grain staining reaction & - & - \\
\hline Cell morphology & Rod & Rod \\
\hline Motility & + & + \\
\hline Swarming on TSA $(2.0 \% \mathrm{NaCl})$ & + & + \\
\hline Growth on TCBS agar & $\mathrm{Y}$ & $\mathrm{Y}$ \\
\hline Growth on MacConkey agar & + & + \\
\hline \multicolumn{3}{|l|}{$\mathrm{NaCl}$ tolerance } \\
\hline TSA $1 \%$ & + & + \\
\hline TSA $8 \%$ & + & + \\
\hline TSA $10 \%$ & - & + \\
\hline TSA $12 \%$ & - & - \\
\hline \multicolumn{3}{|l|}{ Temperature tolerance } \\
\hline $4^{\circ} \mathrm{C}$ & - & - \\
\hline $10^{\circ} \mathrm{C}$ & + & + \\
\hline $40^{\circ} \mathrm{C}$ & + & + \\
\hline $50^{\circ} \mathrm{C}$ & - & - \\
\hline
\end{tabular}

shrimp in each replicate) containing $40 \mathrm{l}$ seawater $\left(20 \%\right.$ ) at $28^{\circ} \mathrm{C}$ with aeration. Shrimp were fed with formulated shrimp feed (Shinta Feed Company) twice a day for up to $6 \mathrm{~d}$. The numbers of moribund and dead shrimp were recorded daily and bacteria were isolated from the tissues of dead shrimp and characterized as described below. The $\mathrm{LD}_{50}$ was calculated based on the program of Trevors \& Lusty (1985).

Histological observations. Muscle tissues of moribund shrimp were fixed in Davidson's solution (Bell \& Lightner 1988). The fixed specimens were embedded in paraffin and cut into $5 \mu \mathrm{m}$ sections, stained with Gram stain and with modified Mayer's hematoxylin and phloxine eosin stain before viewing under the light microscope (Sheehan \& Hrachak 1980).

\section{RESULTS}

\section{Gross signs and histopathology of diseased shrimp}

Shrimp mortality in ponds affected by disease outbreaks was up to $50 \%$ over $6 \mathrm{~d}$. Typical signs of disease included anorexia, poor growth, inactivity, reddish pleural borders of antennae, uropods and telson, and opaque and whitish musculature. Upon histological examination, large numbers of bacteria were present in the musculature. Necrotic musculature was infiltrated with aggregating hemocytes.

\section{Bacterial isolation and characterization}

Six bacterial isolates were obtained from the diseased shrimp from 3 farms and identified as Vibrio. All were Gram-negative, short, motile rods that swarmed on TSA plates. They produced yellow colonies on TCBS agar and grew on MacConkey agar. All strains grew in media containing 1 to $8 \% \mathrm{NaCl}$ and grew over a wide temperature range (from 10 to $40^{\circ} \mathrm{C}$ ). Comparisons with reference strain Vibrio alginolyticus ATCC17749 are shown in Tables 1 \& 2. All 6 strains were sensitive to $0 / 129$, novobiocin, neomycin, nitrofurantoin, chloramphenicol, tetracycline and kanamycin. However, they were slightly resistant to sulfisoxazole.

\section{S rDNA sequence}

The sequence of the $1486 \mathrm{bp} 16$ S rDNA PCR amplicon from Isolate $\mathrm{CH} 003$ was determined and deposited at GenBank under accession number AY373027. This sequence showed $99.9 \%$ identity with the sequence of the reference strain Vibrio alginolyticus ATCC17749 
Table 2. Biochemical characteristics of isolated strains $(n=6)$ from diseased Litopenaeus vannamei in comparison to the reference strain Vibrio alginolyticus ATCC17749. +: positive; -: negative; OPNG: o-nitrophenyl- $\beta$-D-galactopyranoside

\begin{tabular}{|c|c|c|}
\hline Test & Isolated strain & ATCC17749 \\
\hline Catalase & + & + \\
\hline Fermentative & $+/+$ & $+/+$ \\
\hline \multicolumn{3}{|l|}{ API 20E system } \\
\hline \multicolumn{3}{|l|}{ Presence of: } \\
\hline$\beta$-galactosidase (OPNG test) & - & - \\
\hline Arginine dihydrolase & - & - \\
\hline Lysine decarboxylase & + & + \\
\hline Ornithine decarboxylase & - & - \\
\hline Urease & - & - \\
\hline Tryptophane deaminase & - & - \\
\hline Gelatinase & + & + \\
\hline Cytochrome-oxidase & + & + \\
\hline \multicolumn{3}{|l|}{ Production of: } \\
\hline $\mathrm{H}_{2} \mathrm{~S}$ & - & - \\
\hline Indole & + & + \\
\hline Acetoin & - & - \\
\hline $\mathrm{NO}_{2}$ & + & + \\
\hline \multicolumn{3}{|l|}{ Utilization of: } \\
\hline Citrate & - & - \\
\hline Glucose & + & + \\
\hline Mannitol & + & + \\
\hline Inositol & - & - \\
\hline Sorbitol & + & + \\
\hline Rhamnose & - & - \\
\hline Sucrose & + & + \\
\hline Melibiose & - & - \\
\hline Amygdalin & - & - \\
\hline Arabinose & - & - \\
\hline
\end{tabular}

(GenBank accession number X74690) and V. alginolyticus 16S rDNA (GenBank accession number X74691) (Ruimy et al. 1994). Results from morphology, biochemical tests and 16S rDNA indicated that the isolates were $V$. alginolyticus.

\section{Experimental infections}

Shrimp injected with isolate CH003 developed opaque and whitish musculature, and reddish pleural borders of antennae, uropods and telsons, and eventu- ally died. A bacterial dose of $4 \times 10^{6} \mathrm{CFU}$ induced $80 \%$ mortality in $72 \mathrm{~h}$ at $28^{\circ} \mathrm{C}$. A dose of $4 \times 10^{4} \mathrm{CFU}$ caused $23 \%$ mortality, with similar gross signs and histopathology in moribund shrimp over 48 to $144 \mathrm{~h}$ (Table 3). The calculated $96 \mathrm{~h} \mathrm{LD}_{50}$ was $3.0 \times 10^{5} \mathrm{CFU}$ shrimp $^{-1}$, which was equivalent to $6.6 \times 10^{4} \mathrm{CFU} \mathrm{g}^{-1}$ body weight. The infected shrimp displayed necrotic musculature infiltrated by hemocytes. Survival of control shrimp was $100 \%$ and muscle tissue was normal. Re-isolation of the injected bacteria from the moribund shrimp confirmed Koch's postulates.

\section{DISCUSSION}

In decapod crustaceans, several environmental factors, such as salinity, temperature and low dissolved oxygen, can cause opaque and whitish musculature. This opaque and whitish musculature commences at the tail and progresses to the head, which then turns to red (Lakshmi et al. 1978, Lightner 1983). These changes are reversible during the initial stages of development, if the causative stressor is eliminated. Body opaqueness has been observed in Vibrio campebelli-infected larvae of Penaeus monodon and Fenneropenaeus indicus (Hameed 1995). Body opaqueness, necrosis and lethargy have been observed in Litopenaeus vannamei larvae and postlarvae infected by Vibrio harveyi, V. parahaemolyticus and V. penaeicida (Aguirre-Guzmán et al. 2001). Similar gross signs and histopathology were seen in our field specimens and laboratory-challenged specimens.

Of the Vibrio species described in Bergey's Manual of Systematic Bacteriology, V. alginolyticus, $V$. anguillarum, V. parahaemolyticus and $V$. harveyi have been described as pathogenic to penaeid shrimp (Lightner 1983, Takahashi et al. 1985). V. alginolyticus isolated from moribund Penaeus monodon was reported to kill P. monodon and Maruspenaeus japonicus with an $\mathrm{LD}_{50}$ of $1.13 \times 10^{5}$ and $2.46 \times 10^{5} \mathrm{CFU} \mathrm{g}{ }^{-1}$ body weight, respectively (Lee et al. 1996a,b). Our $\operatorname{LD}_{50}$ for $V$. alginolyticus in Litopenaeus vannamei was similar $\left(3.0 \times 10^{5} \mathrm{CFU}\right.$ shrimp ${ }^{-1}$ or $6.6 \times 10^{4} \mathrm{CFU} \mathrm{g}^{-1}$ body weight).

Table 3. Experimental infection of Litopenaeus vannamei injected with isolated strain Vibrio alginolyticus (CH003). Cumulative mortality $(\%)$ data in the same column having different superscripted letters are significantly different $(p<0.05)$

\begin{tabular}{|c|c|c|c|c|c|c|c|}
\hline \multirow{2}{*}{$\begin{array}{l}\text { Bacterial dose } \\
\left(\text { CFU shrimp }{ }^{-1} \text { ) }\right.\end{array}$} & \multirow{2}{*}{$\begin{array}{l}\text { No. } \\
\text { shrimp }\end{array}$} & \multicolumn{6}{|c|}{ Time after challenge (h) } \\
\hline & & 6 & 12 & 24 & 48 & 72 & 144 \\
\hline Saline & 30 & 0 & 0 & 0 & 0 & 0 & 0 \\
\hline $4 \times 10^{4}$ & 30 & 0 & $0^{\mathrm{a}}$ & $16.7 \pm 3.3^{b}$ & $23.3 \pm 3.3^{c}$ & $23.3 \pm 3.3^{c}$ & $23.3 \pm 3.3^{c}$ \\
\hline $4 \times 10^{5}$ & 30 & 0 & $10.0 \pm 5.8^{\mathrm{a}}$ & $46.7 \pm 6.7^{a}$ & $56.7 \pm 3.3^{b}$ & $56.7 \pm 3.3^{b}$ & $56.7 \pm 3.3^{b}$ \\
\hline $4 \times 10^{6}$ & 30 & 0 & $3.3 \pm 3.3^{\mathrm{a}}$ & $53.3 \pm 3.3^{\mathrm{a}}$ & $76.7 \pm 3.3^{\mathrm{a}}$ & $80.0 \pm 5.8^{\mathrm{a}}$ & $80.0 \pm 5.8^{\mathrm{a}}$ \\
\hline
\end{tabular}


Vibriosis in penaeid shrimp is generally recognized as a secondary infection influenced by factors such as stress, environmental failures and high numbers of potentially pathogenic bacteria in the enviromment (Mohney et al. 1994, Lavilla-Pitogo et al. 1998). Changes in environmental factors such as salinity, $\mathrm{pH}$ and ammonia are capable of altering the virulence of Vibrio harveyi and V. alginolyticus (Prayitno et al. 1995, Liu \& Chen 2004). For example, we previously showed that immune capacity and resistance to $V$. alginolyticus decreased in Litopenaeus vannamei exposed to ammonia (Liu \& Chen 2004). Further work is needed on the effect of deteriorated pond water environments on shrimp immune capability and disease outbreaks. A topic of particular interest would be the effect of low salinity cultivation, since it is now commonly practiced with L. vannamei in Taiwan.

Acknowledgements. This study was supported by a grant (NSC 91-2317-B-020-003) from the National Science Council, Taiwan, ROC.

\section{LITERATURE CITED}

Aguirre-Guzmán G, Vazquez-Juarez R, Ascencio F (2001) Differences in the susceptibility of American white shrimp larval substages (Litopenaeus vannamei) to four Vibrio species. J Invertebr Pathol 78:215-219

Aznar R, Ludwig W, Schleifer KH (1993) Ribotyping and randomly amplified polymorphic DNA analysis of Vibrio vulnificus biotypes. Syst Appl Microbiol 16:303-309

Baumann P, Schubert RHW (1984) Family II. Vibrionaceae. Veron 1965, 5345. In: Krieg NR, Holt JG (eds) Bergey's Manual of Systematic Bacteriology, Vol 1. Williams \& Wilkins, Baltimore, MD, p 516-550

Bell TA, Lightner DV (1988) A handbook of normal penaeid shrimp histology. World Aquaculture Society, Baton Rouge, LA

Benson D, Bogusk M, Lipman DJ, Ostell J (1994) Genbank. Nucleic Acids Res 22:3441-3444

Chen SN, Chang PS, Kou GH (1989) Observation on pathogenicity and epizootiology of Penaeus monodon baculovirus (MBV) in cultured shrimps in Taiwan. Fish Pathol 24:189-195

Cheng W, Chen JC (1998) Isolation and characterization of an Enterococcus-like bacterium causing muscle necrosis and mortality in Macrobrachium rosenbergii in Taiwan. Dis Aquat Org 34:93-101

Costa R, Mermoud I, Koblavi S, Morlet B, Haffner P, Berthe F, Legroumellec M, Grimont P (1998) Isolation and characterization of bacteria associated with a Penaeus stylirostris disease (Syndrome 93) in New Caledonia. Aquaculture 164:297-309

Diggles BK, Carson J, Hine PM, Hickman RW, Tait MJ (2000) Vibrio species associated with mortalities in hatcheryreared turbot (Colistium nudipinnis) and brill (C. guntheri) in New Zealand. Aquaculture 183:1-12

Facklam RR, Carey RB (1985) Streptococci and Aerococci. In: Lennette EH, Balows A, Hausler WJ, Shadomy HJ (eds) Manual of clinical microbiology, 4th edn. American Society for Microbiology, Washington, DC, p 154-175
Hameed ASS (1995) Susceptibility of three Penaeus species to a Vibrio campbellii-like bacterium. J World Aquacult Soc 26:315-318

Higgins DG, Sharp PM (1988) CLUSTAL: a package for performing multiple alignment on a microcomputer. Gene 73:237-244

Kim MS, Jeong HD (2001) Development of 16S rRNA targeted PCR methods for the detection and differentiation of Vibrio vulnificus in marine environments. Aquaculture 193: 199-211

Kong RYC, Pelling A, So CL, Wu RSS (1999). Identification of oligonucleotide primers targeted at the 16S-23S rDNA intergenic spacers for genus- and species-specific detection of Aeromonas. Mar Pollut Bull 38:802-808

Lakshmi GJ, Venkataramiah A, Howse HD (1978) Effect of salinity and temperature change on spontaneous muscle necrosis in Penaeus aztecus. Aquaculture 13:35-43

Lavilla-Pitogo CR, Leano EM, Paner MG (1998) Mortalities of pond-cultured juvenile shrimp, Penaeus monodon, associated with dominance of luminescent vibrios in the rearing environment. Aquaculture 164:337-349

Lee KK, Yu SR, Chen FR, Yang TZ, Liu PC (1996a). Virulence of Vibrio alginolyticus isolated from diseased tiger shrimp Penaeus monodon. Curr Microbiol 32:229-231

Lee KK, Yu SR, Yang TL, Liu PC, Chen FR (1996b) Isolation and characterization of Vibrio alginolyticus isolated from diseased kuruma prawn, Penaeus japonicus. Lett Appl Microbiol 22:111-114.

Lightner DV (1983) Diseases of culture penaeid shrimp. In: McVey JP (ed) CRC handbook of mariculture, Vol 1. Crustacean aquaculture. CRC Press, Boca Raton, FL, p 289-320

Lightner DV, Hedrick RP, Fryer JL, Chen SN, Liao IC, Kou GH (1987) A survey of cultured penaeid shrimp in Taiwan for viral and other important diseases. Fish Pathol 22:127-140

Lin MN, Ting YY, Tzeng BS, Liu CY (1990) Penaeid parental shrimp rearing: culture of the third generation in Penaeus vannamei. J Fish Soc Taiwan 17:125-132

Liu CH, Chen JC (2004) Effect of ammonia on the immune reponse of white shrimp Litopenaeus vannamei and its susceptibility to Vibrio alginolyticus. Fish Shellfish Immunol 16:321-334

Liu PC, Lee KK, Chen SN (1996a) Pathogenicity of different isolates of Vibrio harveyi in tiger prawn, Penaeus monodon. Lett Appl Microbiol 22:413-416

Liu PC, Lee KK, Yii KC, Kou GH, Chen SN (1996b) Isolation of Vibrio harveyi from diseased Kuruma prawns Penaeus japonicus. Curr Microbiol 33:129-132

Lo CF, Kou GH (1998) Virus-associated white spot syndrome of shrimp in Taiwan: a review. Fish Pathol 33:365-371

Mohney LL, Lightner DV, Bell TA (1994) An epizootic of vibriosis in Ecuadorian pond-reared Penaeus vannamei Boone (Crustacea: Decapoda). J World Aquacult Soc 25: 116-125

Prayitno SB, Latchford JW (1995) Experimental infections of crustaceans with luminous bacteria related to Photobacterium and Vibrio. Effect of salinity and $\mathrm{pH}$ on infectiosity. Aquaculture 132:105-112

Ruimy R, Breittmayer V, Elbaze P, Lafay B, Boussemart O, Gauthier M, Christen R (1994) Phylogenetic analysis and assessment of the genera Vibrio, Photobacterium, Aeromonas, and Plesiomonas deduced from small-subunit rRNA sequences. Int J Syst Bacteriol 44:416-426

Sakazaki R (1968) Proposal of Vibrio alginolyticus for biotype 2 Vibrio parahaemolyticus. Jap J Med Sci Biol 21:359-326

Sanger F, Nicklen S, Coulson AR (1977) DNA sequencing with chain-terminating inhibitors. Proc Natl Acad Sci USA 
74:5463-5467

Sheehan DC, Hrachak BB (1980) Theory and practice of histotechnology, 2nd edn. CV Mosby, St. Louis, MO

Song YL, Cheng W, Wang CH (1993) Isolation and characterization of Vibrio damsela infectious for cultured shrimp in Taiwan. J Invertebr Pathol 61:24-31

Sudheesh PS, Jie K, Xu HS (2002) Random amplified polymorphic DNA-PCR typing of Vibrio parahaemolyticus and $V$. alginolyticus isolated from cultured shrimps. Aquaculture 207:11-17

Sung HH, Hsu SF, Chen CK, Ting YY, Chao WL (2001) Relationships between disease outbreak in cultured tiger shrimp (Penaeus monodon) and the composition of Vibrio communities in pond water and shrimp hepatopancreas during cultivation. Aquaculture 192:101-110

Takahashi Y, Shimoyama Y, Momoyama K (1985) Pathogenic-

Editorial responsibility: Timothy Flegel,

Bangkok, Thailand ity and characteristics of Vibrio sp. isolated from cultured kuruma prawn Penaeus japonicus. Bull Jpn Soc Sci Fish 51:721-730

Trevors JS, Lusty CW (1985) A base microcomputer program for calculating $\mathrm{LD}_{50}$ values. Water Air Soil Pollut 24: $431-442$

Urakawa H, Tsukamoto K, Ohwada K (1997) 16S rDNA genotyping using PCR/RFLP (restriction fragment length polymorphism) analysis among the family Vibrionaceae. FEMS Microbiol Lett 152:125-132

Wang YC, Chang PS (2000) Yellow head virus infection in the tiger prawn Penaeus monodon cultured in Taiwan. Fish Pathol 35:1-10

Yu CI, Song YL (2000) Outbreaks of Taura syndrome in Pacific white shrimp (Penaeus vannamei) cultured in Taiwan. Fish Pathol 35:21-24

Submitted: April 9, 2004; Accepted: June 29, 2004

Proofs received from author(s): October 1, 2004 